\title{
Building or Renovating Libraries: A Bibliography of Government Documents
}

\author{
Kathleen Eisenbeis and Carson Holloway
}

\section{Introduction}

Federal and state documents are a valuable source of information for the librarian interested in library architecture and construction. This bibliography provides a selected list of government publications concerning standards and current practice in architecture for public buildings in which category libraries are placed. Emphasis is on documents that the librarian needs to be familiar with in order to participate as a member of the design team. The publications listed cover both renovation and construction from the ground up.

This bibliography includes laws and regulations at the state and federal level, information on barrier-free access and handicapped access, efficient energy use in buildings, preservation of historic buildings and sites, and government publications covering general architectural matters.

Generally, federal documents include information which applies to all the states. Other than building codes and regulations, there is little information which concerns architecture in publications from the various states. The only state documents which are listed in the bibliography are those published by the state of North Carolina.

Not included in this survey are the standards or publications from professional societies or voluntary standards organizations such as the American National Standards Institute (ANSI), the American Library Association, or other groups concerned with construction, operation, and maintenance of buildings.

\section{Methodology}

Research for this article involved interviews with experts, a review of bibliographic sources from 1970 to the present, and the examination of primary source material such as laws, codes, and regulations.

Interviews with experts emphasized the fact that the more completely the librarian understood the design process and the relevant design issues, the more successful the finished library was likely to be. Documents are often used by professional architects and these documents are equally useful to the librarian who is studying library architecture. 
The review of bibliographic sources included the Monthly Catalog of U.S. Government Publications, the G.P.O. Sales Publications Reference File, the Public Affairs Information Service Bulletin, and the State Publications Index (formerly Checklist of State Publications). These indices provided a substantial block of material from which this bibliography was derived.

\section{Acknowledgements}

The authors wish to thank Jerrold Orne; Frank DePasquale and John Thompson of DePasquale, Markham, Thompson, Wilson Architects and Planners, Ltd. of Durham; Ronald Mace of Barrier Free Environments, Raleigh, N.C.; and, Allyn Simon of the Public Documents and Maps Department, Perkins Library, Duke University.

\section{Selected Bibliography}

The first documents which a librarian will become aware of in the planning process are the federal and state building codes and regulations. Primary source material such as the U.S. Code of Federal Regulations, the U.S. Code, the General Statutes of North Carolina, and the North Carolina State Building Code provide the legal framework which influences much of current practice in library architecture. In addition to the normal state and local codes pertaining to public welfare and safety, the use of federal funds in building or renovation requires that specific agency standards be met. The Architectural and Transportation Barriers Compliance Board was created by Congress by the Rehabilitation Act of 1973 (Public Law 93-112) to ensure compliance with standards for making public buildings accessible to and usable by the physically handicapped persons. Any library facility financed wholly or in part with federal grants or loans must meet federal accessibility standards. A pamphlet explaining the purpose and organization of the Board and another pamphlet, Laws Concerning the Federal Architectural and Transportation Barriers Compliance Board, are available on request from the Architectural and Transportation Barriers Compliance Board, Rm. 1010 Switzer Bldg., 330 C St., S. W., Washington, D.C. 20201, telephone 202-245-1591.

Each publication annotated below was reviewed by the authors of this article for relevance and timeliness. The citations also include the Government Printing Office sales Stock Number $(\mathrm{S} / \mathrm{N})$ necessary for ordering the materials.

\section{HANDICAPPED ACCESSIBILITY}

North Carolina. Department of Insurance and the Governor's Study Committee on Architectural Barriers. An Illustrated Handbook of the Handicapped Section of the North Carolina State Building Code, by Ronald Mace. Edited by Betsy Laslett. Raleigh, N.C., 1974, and reprinted 1976. 
North Carolina. Department of Insurance. North Carolina Building Code Council. North Carolina State Building Code. Raleigh, N.C., 1978 edition with 1979 amendments.

Chapter XI: Means of Egress.

North Carolina. Department of Insurance. Special Office for the Handicapped. Accessibility Modifications: Guidelines for Modifications to Existing Buildings for Accessibility to the Handicapped, by Ronald Mace. Raleigh, NC, 1976.

This work outlines modifications that can be made to existing buildings. It does an excellent job of identifying problem areas of modification and acceptable solutions to those problems. Well illustrated and clearly written.

U.S. Code of Federal Regulations Title 24, Part 41.

"Enforcement of building standards for accessibility by the physically handicapped."

U.S. Architectural and Transportation Barriers Compliance Board. Resource Guide to Literature on Barrier-free Environments with Selected Annotations. Washington, D.C.: GPO, 1980. 2nd ed. (Y3.B27:9R 31/980) S/N 017-090-00049-6 \$7.50

The section on public buildings includes references for libraries. More comprehensive than ather bibliographies on barrier-free design.

U.S. Community Services Administration. Accessibility Assistance: a Directory of Consultants on Environments for Handicapped People, compiled by the National Center for a Barrier Free Environment. Washington, D.C.: GPO, 1978. (CSA 1.2: Ac 2) S/N 059-000-00056-0 \$3.25

$A$ list of free and paid consultants and agencies. Lists six sources of assistance in North Carolina. Listings were voluntary on the part of the consultants, and include contact person, services provided, accessibility projects in the past and references. A helpful source to determine professional assistance in this field. Slightly old. Inclusion in this directory does not mean a recommendation on the part of the Community Services Administration.

U.S. Department of Education. Office of Special Education and Rehabilitative Services. Office of Handicapped Individuals. Architectural Barriers Removal: Information Resources, Funding Guide, Publications Available from Federal Sources. Washington, D.C.: GPO, 1980. (ED 1.8:Ar2) S/N 065-00000060-1 $\$ 2.50$

This book is an information source which lists large organizations such as the American Institute of Architects and describes their programs on barrier removal, provides a guide to federal loans and other forms of funding for alterations, and 
lists government publications on barrier removal. The style is straightforward, a good reference source.

U.S. Department of Housing and Urban Development. Office of Policy Development and Research. Access to the Built Environment: $a$ Review of the Literature. Washington, D.C.: GPO, 1979. (HH 1.2:En8/4) S/N 023-00000516-6 $\$ 4.75$

This is the first in a series of six publications done under the direction of Edward Steinfeld, Department of Architecture, State University of New York at Buffalo for the Department of Housing and Urban Development. The purpose of the project was to revise and augment ANSI Standards A 117.1: "Specifications for Making Buildings and Facilities Accessible to and Usable by, the Physically Handicapped." Reviewing the current state of the art in knowledge regarding barrier free design to that date, the book includes an excellent chapter summarizing existing federal, state and municipal legislation and regulations on barrier free design: Chapter 4 "Accessibility Codes and Regulations." Listed below are some of the other useful titles in the series.

U.S. Department of Housing and Urban Development. Office of Policy Development and Research. Accessible Buildings for People with Severe Visual Impairments, by James Aiello. Washington, D.C.: GPO, 1979. (HH1.2:B86/4) S/N 023-000-00515-8 \$4.00.

U.S. Department of Housing and Urban Development. Office of Policy Development and Research. Accessible Buildings for People with Walking and Reaching Limitations. Washington, D.C.: GPO, 1979. (HH 1.2: B 86/3) S/N 023-000-00509-3 \$4.75.

U.S. Department of Housing and Urban Development. Office of Policy Development and Research. Barrier Free Site Design. Washington, D.C.: GPO, 1976. (HH 1.2: B27) S/N 023-000-00291-4 \$4.00.

This guide was done under contract by the American Society of Landscape Architects Foundation. The text and clear drawings emphasize that barrier free access is not just for the handicapped and that initial planning can make this access cost competitive with conventional systems. References are made to the appropriate laws. Plans show how sites can be adapted to barrier-free design.

U.S. Department of Housing and Urban Development. Office of Policy Development and Research. Estimated Cost of Accessible Buildings, by Steven Schroeder and Edward Steinfeld. Washington, D.C.: GPO, 1979. (HH1.2: B86/5) S/N 023-000-00510-7 \$4.75. 
U.S. Department of Housing and Urban Development. Office of Policy Development and Research. Selected Bibliography on Barrier-free Design, by Edward Steinfeld. Washington, D.C.: GPO, 1979. (HH1.23: B 27) S/N023-000. 00512-3 \$1.50.

A good annotated bibliography which contains references to sources on designing buildings which consider the needs of the physically handicapped. All the materials included were judged by the author to be well illustrated, comprehensive and easy to obtain.

U.S. Library of Congress. National Library Service for the Blind and Physically Handicapped. Planning Barrier-free Libraries, by Charles A. Moss, Jr. Washington, D.C.: GPO, 1981. (LC19.6/2:B27).

A new guide specifically for the renovation and construction of libraries serving blind and physically handicapped readers.

\section{HISTORICAL RENOVATION.}

U.S. Department of Commerce. National Bureau of Standards. Assessment of Current Building Regulatory Methods as Applied to the Needs of Historic Preservation Projects. Washington, D.C.: GPO, 1978. (C 13.1:524).

Examples of the conflicts which arise in the process of adaptive re-use of historic structures between health and safety requirements in the building regulatory system and the needs of historic building preservation. One of the examples is the Hezekiah Alexander House in Charlotte. This publication gives an idea of the problems that can arise in preservation.

U.S. Department of Education. National Center for a Barrier Free Environment. Adapting Historic Campus Structures for Accessibility, by Margaret Milner. Washington, D.C.: GPO, 1978. (ED 1.2:C15) S/N 065-000-0034-2 \$4.25. Reviews the issues involved in making accessibility modifications to buildings of historic value, architectural significance or traditional interest. The information can be applied not only to "historical" but also to older buildings. This source could be useful for generating ideas for innovative solutions to unique problems found in older campus buildings.

\section{ENERGY}

U.S. Department of Commerce. National Bureau of Standards. Center for Building Technology. Simplified Energy Design Economics: Principles of Economics Applied to Energy Conservation and Solar Energy Investments in Buildings, by Harold E. Marshall and Rosalie T. Ruegg. Washington, D.C.: GPO, 1980. (C 13.10:544) S/N 033-033-2156-3 \$3.50.

As a member of the design team, the librarian may need to understand the 
economic principles behind design choices related to energy conservation methods. This book addresses that information need. This is a handbook which will "aid your understanding and facilitate your cooperation with experts retained to conduct more complex economic analysis." Topics covered include economic efficiency, measuring costs and benefits and discounting. Information is presented in simple form and illustrative examples are given.

U.S. Department of Energy. Office of Conservation and Solar Energy. Federal Programs Office. Architects and Engineers Guide to Energy Conservation in Existing Buildings. Washington, D.C.: GPO, 1980. (E 1.26: 0132) S/N 061000-00394-1 \$9.00.

This is a technical work which will be of use to librarians as a reference book. Information on surveying a building for energy use and opportunities for conservation in the various systems of a building are discussed. The introductory material provides good background on the issues involved. A glossary is included.

U.S. Federal Energy Administration. Office of Energy Conservation and Environment. Office of Building Programs. Energy Conservation in New Building Design: an Impact Assessment of ASHRAE. Standard 9075, prepared by Arthur D. Little, Inc. Conservation paper number 43-B. Washington, D.C.: GPO, 1976. (FE 1.22:43B) S/N 041-018-00098-4 \$3.75.

This study, done at the request of the National Conference of States on Building Codes and Standards, looks at the costs involved with meeting ASHRAE Standard 9075, the first major voluntary standard concerning energy utilization. The standard was released in August, 1975 by the American Society of Heating, Refrigerating and Air Conditioning Engineers (ASHRAE).

\section{GENERAL}

U.S. Department of Commerce. National Bureau of Standards. Building for People: Behavioral Research Approaches and Directions, by Arthur I. Rubin and Jacqueline Elder. National Bureau of Standards Special Publication 474. Washington, D.C.: GPO, 1980. (C 13.10:474) S/N 003-003-01803-1 \$14.00. As stated in the Preface, "this work is designed as a response to increasing demands that buildings meet the needs of those who occupy them." This is a practical, easy-to-use guide to information on how buildings and people influence one another, known as the study of $\mathrm{M} / \mathrm{E}$ ( Man/Environment) relationships. Includes information on such topics as appropriate lighting, noise levels and use of color. Recommended.

U.S. Department of Justice. National Institute of Law Enforcement and Criminal Justice. Architectural Design for Crime Prevention, by Oscar Newman. Washington, D.C.: GPO, 1971. (J1.2: Ar2) S/N 027-000-00161-1 \$2.95. 
Although primarily concerned with housing, this study examines the use of "defensible space" in effective design techniques which can help reduce crime. May be useful if crime prevention is a consideration.

\section{Conclusion}

Planning a library, renovation or construction from the ground up can be frustrating as well as exciting. The librarian who is aware of current codes and standards with which the library must comply will be more readily equipped to deal with architects and consultants. Conceptual planning will involve not only the space needs but also problems and restrictions based on standards for safety, energy conservation and even historic preservation. All of these things affect the total cost. The librarian should be prepared to compromise on ideal size and space needs, because available funds must also be used to comply with code requirements. A good architect, experienced in library planning, will be invaluable in this process.

Kathleen Eisenbeis and Carson Holloway are Documents Librarians, Perkins Library, Duke University.

\section{Personalized Subscription Servic

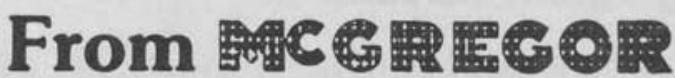

In today's computer world, it is nice to know librarians communicate with their own McGregor "home office" representative.

Title changes, research, additions, cancellations or plain problems are handled promptly by a simple phone call or letter.

This saves librarians time, while keeping their subscription portfolio current at all times.

McGregor serves libraries large and small with all American and foreign titles.
Our prepayment plan, collective single invoicing and automatic renewal option makes library management easier and more efficient.

Write for your free McGregor service brochure today.

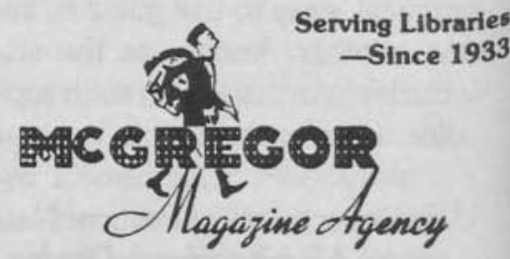

Mt. Morris, Illinois 61054 